\title{
PENGARUH KEPEMIMPINAN DAN PEMBERDAYAAN TERHADAP MOTIVASI DAN KINERJA PEGAWAI
}

\author{
I Putu Magna Anuraga ${ }^{1}$ \\ Desak Ketut Sintaasih ${ }^{2}$ \\ I Gede Riana ${ }^{3}$
}

\author{
${ }^{1,2,3}$ Fakultas Ekonomi dan Bisnis Universitas Udayana (Unud), Bali, Indonesia \\ Email:nana_anuraga@yahoo.com
}

\begin{abstract}
ABSTRAK
Kinerja merupakan hasil kerja yang dihasilkan oleh karyawan sesuai dengan perannya dalam organisasi. Kinerja karyawan merupakan salah satu hal yang sangat penting dalam suatu organisasi untuk mencapai tujuan sehingga berbagai usaha harus dilakukan organisasi untuk meningkatkanya. Penelitian ini bertujuan untuk menganalisis pengaruh kepemimpinan dan pemberdayaan pegawai terhadap motivasi kerja dan kinerja pegawai. Penelitian ini dilakukan di Dinas Pendidikan Pemuda dan Olah Raga Kabupaten Tabanandengan menggunakan sampel jenuh yaitu 59 orang pegawai PNS. Data dikumpulkan dengan melakukan interview dan penyebaran kuesioner. Selanjutnya data yang telah terkumpul dianalisis dengan menggunakan analisis deskriptif dan analisis Partial Least Square. Hasil penelitian ini menyimpulkan bahwa kepemimpinan berpengaruh positif signifikan terhadap motivasi kerja. Pemberdayaan berpengaruh positip signifikan terhadap Kinerja pegawai dan motivasi kerja. Motivasi kerja berpengaruh positip signifikan terhadap Kinerja pegawai. Selanjutnya Kepemimpinan berpengaruh positip tidak signifikan terhadap Kinerja pegawai.
\end{abstract}

Kata kunci :kepemimpinan. Pemberdayaan, motivasi, kinerja.

\begin{abstract}
Performance is the result of work produced by employees in accordance with its role in the organization. Employee performance is one very important thing in a company to achieve the goal that every effort should be made to the company of increasing. This study aimed to analyze the influence of leadership and empowerment of employees on work motivation and performance of employees. This research was conducted at the Department of Education Youth and Sports Regency Tabanan using sample that 59 employees. Data were collected by conducting interviews and questionnaires. Subsequently collected data were analyzed using descriptive analysis and Partial Least Square. The results of this study concluded that the leadership is significant positive effect on work motivation. Empowerment is significant positive effect on employee performance and motivation. Work motivation is significant positive effect on employee performance. Furthermore, Leadership is not significant positive effect on employee performance.
\end{abstract}

Keywords: leadership, empowerment, motivation.performance 


\section{PENDAHULUAN}

Sumber daya manusia dapat mempengaruhi keberhasilan suatu organisasi. Dalam era globalisasi, kemampuan SDM yang berkualitas sangatlah penting, karena mempunyai peranan yang sangat besar dalam kegiatan organisasi. SDM adalah harta yang paling berharga dan paling penting dimiliki oleh suatu organisasi, karena keberhasilan suatu organisasi sangat ditentukan oleh unsur manusia.Visi, misi, dan tujuan dari suatu organisasi yang telah direncanakan sebelumnya sangat tergantung pada berbagai faktor yang mempengaruhi dalam pencapainnya. Salah satu faktor yang mempengaruhi suatu organisasi dalam mencapai visi, misi, dan tujuan adalah SDM dimiliki oleh organisasi tersebut. SDM memiliki peranan penting dalam setiap kegiatan suatu organisasi. SDM merupakan motor penggerak jalannya suatu organisasi dan merupakan asset terpenting bagi organisasi.

Kinerja merupakan hasil kerja yang dihasilkan oleh karyawan sesuai dengan peranannya dalam organisasi (Manullang, 2007). Menurut Tohardi (2002) kinerja merupakan hasil kerja seorang pekerja didalam sebuah proses manajemen atau suatu organisasi secara keseluruhan dimana hasil kerja tersebut dapat ditunjukkan buktinya secara kongkrit dan dapat diukur (dibandingkan secara standar yang telah ditentukan). Kinerja merupakan hasil kerja yang dihasilkan oleh karyawan sesuai dengan perannya dalam organisasi (Hariandja,2002).Menurut Bernardin dan Russel (1993:379) "A way of measuring the contribution of individuals to their organization" yang artinya penilaian kinerja adalah cara mengukur konstribusi individu (karyawan) kepada organisasi tempat mereka bekerja. Penilaian prestasi kerja (performance appraisal) adalah suatu proses yang digunakan pimpinan untuk 
menentukan apakah seseorang karyawan melakukan pekerjaannya sesuai dengan tugas dan tanggung jawabnya.

Terdapat beberapa faktor yang mempengaruhi kinerja karyawan seperti sikap mental (berupa motivasi kerja, disiplin kerja dan etika kerja), pendidikan dan pelatihan, keterampilan, manajemen, tingkat penghasilan, gizi dan kesehatan, jaminan sosial, lingkungan dan iklim kerja, sarana produksi, teknologi, dan kesempatan berprestasi (Nitisemito,2000). Sedarmayanti (2007), menyatakan faktor faktor yang mempengaruhi kinerja karyawan diantaranya adalah sikap mental, pendidikan, keterampilan, manajemen, Hubungan Industrial Pancasila (HIP), tingkat penghasilan, gizi dan kesehatan, jaminan sosial, lingkungan dan iklim kerja, sarana produksi, teknologi, kesempatan berprestasi. Dengan memperhatikan faktorfaktor yang mempengaruhi kinerja pegawai tersebut, diharapkan dapat meningkatkan kinerja pegawai.

Beberapa penelitian menunjukkan bahwa kinerja dapat dipengaruhi oleh beberapa faktor. Seperti penelitian Dionne et al. (2004), menunjukkan bahwa kinerja dipengaruhi oleh kepemimpinan. Pemimpin dalam pengertian ialah seorang yang dengan jalan memprakarsai tingkah laku sosial dengan mengatur, mengarahkan, mengorganisir atau mengontrol usaha/upaya orang lain atau melalui prestise, kekuasaan dan posisi. Dalam pengertian yang terbatas, pemimpin ialah seorang yang membimbing, memimpin dengan bantuan kualitas-kualitas persuasifnya dan akseptansi/ penerimaan secara sukarela oleh para pengikutnya (Henry, 1996:33). Penelitian Chow et al. (2006), membuktikan bahwa kinerja dipengaruhi oleh pemberdayaan karyawan. Selain itu Wang (2009), menunjukkan kinerja dipengaruhi oleh motivasi. Brenda (2001) menyatakansecara 
luasdiakuibahwahubunganantara organisasidan tren motivasimemberikan dampak positif denganproduktivitaskaryawan. Dalam studi ini dilaporkan motivasi laten memiliki dampak pada retensi laten, dengan persepsi manajemen atas pengembangan karir karyawan untuk mendukung operasional organisasi. Christine et al. (2009) memprediksi untuk memahami motivasi kerja dapat dibagi menjadi sub-kelompok pekerja atas dasar motivasi kerja mereka. Motivasi kerja memberikan dukungan pada seseorang lebih peduli tentang sosialisasi daripada kepentingan pribadi mereka.

Motivasi merupakan dorongan yang terdapat dalam diri seseorang untuk berusaha mengadakan perubahan tingkah laku yang lebih baik dalam memenuhi kebutuhanya, motivasi sebagai perubahan energi dalam diri seseorang yang ditandai dengan munculnya "feeling" dan didahului dengan tanggapan terhadap adanya tujuan (Mc.Donald and Morgan, 2002:73).Motivasi seorang pegawai dalam suatu organisasi dapat dipengaruhi oleh beberapa faktor. Penelitian yang dilakukan oleh Chipunza et al. (2011), bahwa motivasi dapat dipengaruhi oleh kepemimpinan. Sementara penelitian yang dilakukan oleh Swarnalatha and Prasanna (2012) membuktikan bahwa motivasi dipengaruhi oleh pemberdayaan.

Kepemimpinan merupakan kunci dalam kelangsungan hidup suatu organisasi, karena pimpinan merupakan pencetus tujuan dari suatu organisasi, merencanakan, mengorganisasikan dan menggerakkan seluruh sumber daya yang dimiliki sehingga tercapai tujuan yang diinginkan oleh suatu organisasi. Kepemimpinan yang baik akan berdampak baik terhadap organisasi (Bernadine dan Susilo, 2002:112). Pinar (2011) menyatakan seorang pemimpin dalam organisasi harus dapat menciptakan integrasi yang serasi dengan para bawahannya juga 
termasuk dalam membina kerja sama, mengarahkan dan mendorong gairah kerja para bawahannya sehingga terciptanya motivasi positif yang akan menimbulkan niat dan usaha kerja yang maksimal, dan juga didukung oleh motivasi dalam hal ini pemberian reward bagi karyawan yang berprestasi, cara dan pola tingkah laku pemimpin diartikan oleh bawahan sebagai kerjasama dalam menyelesaikan pekerjaan (Flavia et al., 2012).

Pemberdayaan merupakan wewenang untuk membuat keputusan dalam suatu area kegiatan operasi tertentu tanpa harus memperoleh pengesahan orang lain (Luthans, 2011). Empowerment atau pemberdayaan dapat diartikan sebagai perlibatan karyawan yang benar-benar berarti (signifikan) dalam peningkatan kinerja karyawan". Empowerment suatu cara yang amat praktis dan prodiktif untuk mendapatkan yang terbaik dari diri kita dan staf kita (Stewart, 2006:22).Pemberdayaan adalah pemberian wewenang kepada karyawan untuk merencanakan (Planning), mengendalikan (Controlling) dan membuat keputusan atas pekerjaan yang menjadi tanggung jawabnya tanpa harus mendapatkan otorisasi secara eksplisit dari atasannya (Hansen and Mowen, 2007). Catherine et al. (2012) menegaskan pemberdayaan merupakan alat yang dilakukan sebagai rangsangan dalam meningkatkan motivasi serta kinerja karyawan.

Penurunan kinerja dapat terjadi karena kurangnya motivasi karyawan tersebut dalam bekerja. Pimpinan organisasi harus memberdayakan karyawannya agar memiliki motivasi serta etos kerja yang baik sehingga dapat meningkatkan kinerja karyawan, pemberdayaan dapat berupa pemberian tanggung jawab serta wewenang yang lebih sehingga akan tercermin rasa tanggung jawab, semangat kerja maka akan menciptakan keinginan untuk bekerja dan memberikan yang terbaik 
untuk pekerjaannya (Irene et al., 2006). Memiliki motivasi yang tinggi yang tumbuh dari dalam diri pegawai maka akan dapat meningkatkan kinerjanya. Pemberdayaan yang dilakukan oleh organisasi diharapkan mampu meningkatkan kinerja pegawai sehingga tujuan dari organisasi dapat dicapai.

Pemberdayaan pegawai mencakup dua pokok persoalan yang amat penting dalam meningkatkan kinerja organisasi yakni konsep pemberdayaan yang berakar komitmen dan kepercayaan pegawai sebagai suatu strategi dalam menjalankan organisasi. Upaya dalam menghadapi tantangan seperti inilah diperlukan strategi pemberdayaan pegawai dalam hal ini pemberdayaan struktural, dengan dasar pandangan bahwa upaya yang dilakukan harus menyentuh langsung pada akar persoalannya yaitu meningkatkan kemampuan pembinaan dan produktivitas kerja, yang merupakan bagian tertinggal melalui pengembangan dan mendinamiskan potensinya dengan kata lain pemberdayaan dan pembinaan (Dianti, 2012).

Dinas Pendidikan Pemuda dan Olahraga dipimpin oleh seorang kepala dinas yang bertugas untuk mengarahkan dan membimbing para pegawai dalam melaksanakan tugas. Kurang maksimalnya kinerja pegawai menyebabkan terhambatnya pembangunan sarana dan prasarana pendidikan disebabkan rendahnya motivasi dan pemberdayaan yang diberikan oleh karyawan pada Dinas Pendidikan Pemuda dan Olah Raga Kabupaten Tabanan. Keberhasilan suatu organisasi dalam mencapai tujuan bergantung kepada kepemimpinan yang mampu menggerakkan semua SDM dan SDA, sarana, dana, dan waktu secara secara efektif dan efisien dalam suatu sistem menejemen yang lebih menjadikan karyawan sebagai mitra kerja daripada sebagai bawahan (John, 2012). 
Pemimpin adalah orang yang membina dan menggerakkan seseorang atau sekelompok orang lain agar mereka bersedia, komitmen dan setia melaksanakan tugas dan tanggung jawabnya di dalam mencapai tujuan organisasi yang telah ditetapkan sebelumnya (Gorda, 2006). Penelitian Dionneet al. (2004), Beverly et al.(2008), Chi et al. (2008) menunjukkan bahwa kepemimpinan berpengaruh signifikan terhadap kinerja.

Variabel lain yang dapat mempengaruhi kinerja pegawai adalah pemberdayaan pegawai. Pemberdayaan merupakan wewenang untuk membuat keputusan dalam suatu area kegiatan operasi tertentu tanpa harus memperoleh pengesahan orang lain (Luthans, 2011). Penelitian Yang dan Choi (2008) menunjukkan bahwa pemberdayaan berdampak signifikan terhadap kinerja tim. Penelitian Chow et al. (2006) juga membuktikanpemberdayaan berpengaruh terhadap kinerja karyawan. Penelitian Conger and Kanungu (1998) pemberdayaan diukur melalui dimensi pemberian tanggungjawab dan wewenang, serta hubungan personel dengan indikator sebagai berikut: kesesuaian tanggungjawab dengan kompetensi awak kapal, kesesuaian pekerjaan dengan keahlian karyawan, ketepatan pengawasan pada karyawan, kepercayaan manajemen terhadap karyawan, keeratan hubungan kerja antara manajemen dengan karyawan, dan ketepatan pembinaan karyawan.

Motivasi merupakan hal yang menyebabkan dan mendukung perilaku karyawan supaya mau bekerja giat dan antusias mencapai hasil yang optimal sehingga akan mencapai suatu prestasi kerjadan memberikan kekuatan yang mengarah kepada pencapaian kebutuhan, memberi kepuasan ataupun mengurangi ketidakseimbangan (Martoyo, 2000). Penelitian Wang (2009) membuktikan bahwa 
motivasi berpengaruh terhadap kinerja. Penelitian yang dilakukan oleh Siwantara (2010) juga menyatakan bahwa motivasi berpengaruh signifikan terhadap kinerja. PenelitianYuniari dan Teni Waisnawini (2009) juga menyebutkan bahwa motivasi berpengaruh terhadap kinerja pegawai. Berdasarkan uraian yang telah disampaikan, maka model konseptual penelitian ini dapat digambarkan pada Gambar 1 sebagai berikut :

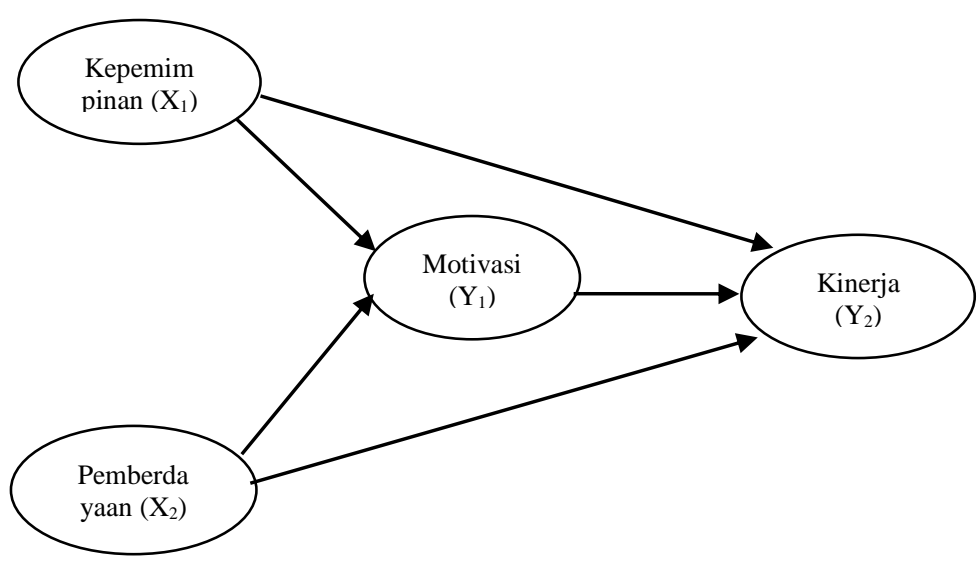

\section{Gambar.1 Kerangka Konseptual Penelitian}

\section{HIPOTESIS PENELITIAN}

Karyawan bekerja dan melakukan tugas serta bertanggung jawab pada pekerjaannya dipengaruhi oleh gaya kepemimpinan (Hsin et al, 2008). Pemimpin dapat mempengaruhi moral dan motivasi kerja, kualitas kehidupan kerja, dan terutama tingkat prestasi dalam suatu organisasi. Beberapa penelitian menunjukkan bahwa terdapat pengaruh signifikan antara kepemimpinan dengan motivasi. Penelitian Chipunza et al. (2011) dan penelitian Chaudhry and Javed (2012) membuktikan terdapat pengaruh antara kepemimpinan dan motivasi. Penelitian Barbuto dan Gifford (2012) juga menunjukan terdapat pengaruh antara kepemimpinan dengan motivasi. 


\section{H1: Kepemimpinan berpengaruh positif dan signifikan terhadap motivasi}

Kapasitas organisasi pemerintahan yang memadai dan penyelenggaraan tata pemerintahan yang baik akan mewujudkan kinerja pegawai yang maksimal (Durga, 2011). Beberapa penelitian menunjukkan terdapat hubungan antara kepemimpinan dengan kinerja. Penelitian Dionneet al. (2004), Beverly et al.(2008), Chi et al. (2008) membuktikan bahwa terdapat hubungan antara kepemimpinan dengan kinerja. Penelitian Pradeep dan Prabhu (2011) menunjukkan bahwa gaya kepemimpinan transformasional memiliki hubungan yang signifikan dengan kinerja. Demikian pula penelitian Sahin (2011) menujukkan adanya hubungan positif antara kepemimpian dengan kinerja.

\section{H2: Kepemimpinan berpengaruh positif dan signifikan terhadap terhadap} kinerja.

Pimpinan organisasi harus memberdayakan karyawannya agar memiliki motivasi serta etos kerja yang baik. Pemberdayaan dapat berupa pemberian tanggung jawab serta wewenang yang lebih sehingga tercermin rasa tanggung jawab yang akan menciptakan keinginan untuk bekerja dan memberikan yang terbaik untuk pekerjaannya (Maryline et al., 1997). Hasil penelitian sebelumnya membuktikan bahwa terdapat hubungan antara pemberdayaan dengan motivasi. Penelitian Swarnalatha dan Prasanna (2012), Tutar et al (2011),Drake et al. (2007) membuktikan terdapat hubungan antara pemberdayaan dengan motivasi. Begitu pula peneitian yang dilakukan oleh Gagne et al. (1997) yang menyebutkan bahwa terdapat hubungan antara pemberdayaan dengan motivasi.

H3: Pemberdayaan berpengaruh positif dan signifikan terhadap motivasi 
Pemberdayaan karyawan bisa memacu untuk meningkatkan kreatifitas, motivasi dan daya inovatif yang dimiliki oleh setiap karyawan dalam melaksanakan tugas dan tanggung jawabnya. Dengan adanya program pemberdayaan karyawan, kinerja karyawan akan meningkat. Sehingga tujuan organisasi akan tercapai dengan baik, cepat dan fleksibel (Andrea, 2007). Hasil penelitian sebelumnya membuktikan bahwa terdapat hubungan antara pemberdayaan dengan kinerja. Seperti penelitian Yang and Choi (2008) bahwa pemberdayaan berdampak signifikan terhadap kinerja tim. Selain itu penelitian yang dilakukan oleh Chow et al. (2006) dan penelitian Ari (2006) menyatakan bahwa pemberdayaan berpengaruh positif terhadap kinerja pegawai.

\section{H4: Pemberdayaan berpengaruh porsitif dan signifikan terhadap kinerja}

Motivasi kerja menjadi tolak ukur tingkat produktivitas yang dapat menghasilkan perkembangan dalam proses operasional. Namun, pada kenyataannya kinerja yang baik tanpa disertai motivasi dapat menganggu kinerja organisasi. Motivasi adalah suatu ketrampilan dalam memadukan kepentingan karyawan dan kepentingan organisasi, sehingga keinginan-keinginan karyawan dipuaskan secara bersamaan dengan tercapainya sasaran-sasaran organisasi secara langsung dapat meningkatkan kinerja karyawan (Fauzilah et al., 2011). Beberapa penelitian menyebutan bahwa motivasi berpengaruh terhadap kinerja. Penelitian tersebut antara lain adalah penelitian yang dilakukan oleh Wang (2009) dan Salleh et al.(2011) yang membuktikan bahwa terdapat hubungan yang positif antara motivasi dengan kinerja. Mawoli and Babandako (2011) dalam penelitiannya menyatakan bahwa motivasi berpengaruh terhadap kinerja. Selain itu Siwantara (2010), Yuniari 
dan Teni Waisnawini (2009) juga menyatakan bahwa motivasi berpengaruh terhadap kinerja pegawai.

H5 : Motivasi berpengaruh positif dan signifikan terhadap kinerja.

\section{METODELOGI PENELITIAN}

Penelitian ini dilakukan di Dinas Pendidikan Pemuda dan Olahraga Kabupaten Tabanan dengan obyek penelitian Kepemimpinan, motivasi kerja, pemberdayaan dan kinerja pegawai. Penelitian ini menggunakan desain causal explanatory untuk menganalisis hubungan antara Kepemimpinan dan pemberdayaan terhadap motivasi kerja dan kinerja. Populasi dalam penelitian ini adalah pegawai pada Dinas Pendidikan Pemuda dan Olahraga Kabupaten Tabanan sebanyak 142 orang karyawan.

Dilihat dari tingkat pendidikan responden, sebagian besar pendidikan terakhirnya adalah strata satu (S1), yaitu sebesar 69,49\%, 25,42 \% adalah berpendidikan Diploma, dan selebihnya yaitu setingkat Magister (S2) 5,08\%. Sedangkan jika dilihat dari masa kerjanya, mayoritas memiliki masa kerja antara 11 tahun sampai dengan 20 tahun, yaitu sebesar 44,06\%, setelah itu dengan masa kerja antara 2 sampai 10 tahun sebesar 32,20\%, selebihnya memiliki masa kerja di atas 21 tahun $23,72 \%$.

Sampel yang diambil berjumlah 142 pegawai Dinas Pendidikan Pemuda dan Olahraga Kabupaten Tabanan dengan karakteristik responden sebagai berikut.

Tabel 1.

Karakteristik Responden

\begin{tabular}{|c|c|c|c|}
\hline No & Keterangan & Jumlah & Prosentase \\
\hline & Jenis kelamin & & \\
\hline & - Laki-laki & 32 & 54,23 \\
\hline & - Perempuan & 17 & 45,77 \\
\hline
\end{tabular}




\begin{tabular}{|c|c|c|c|}
\hline & Total & 59 & 100,0 \\
\hline \multirow[t]{6}{*}{2} & Umur & & \\
\hline & - $\quad 21-30$ tahun & 16 & 27,11 \\
\hline & - $\quad 31-39$ tahun & 22 & 37,28 \\
\hline & - $\quad 40$ - 49 tahun & 11 & 18,64 \\
\hline & - $\quad 50<$ tahun & 10 & 16,94 \\
\hline & Total & 59 & 100,00 \\
\hline \multirow[t]{5}{*}{3} & Tingkat Pendidikan & & \\
\hline & - Setingkat Diploma & 15 & 25,42 \\
\hline & - $\quad$ Setingkat Sarjana & 41 & 69,49 \\
\hline & - $\quad$ Setingkat $\mathrm{S} 2 / \mathrm{S} 3$ & 3 & 5,08 \\
\hline & Total & 59 & 100,0 \\
\hline \multirow[t]{5}{*}{5} & Masa Kerja & & \\
\hline & - $2-10$ tahun & 19 & 32,20 \\
\hline & - $\quad 11-20$ tahun & 26 & 44,06 \\
\hline & - $\quad 21<$ tahun & 14 & 23,72 \\
\hline & Total & 59 & 100,0 \\
\hline
\end{tabular}

Sumber: Data diolah.

Penelitian ini menggunakan data kualitatif dan kuantitatif yang bersumber baik dari sumber primer dan sekunder. Sebelum data dianalisis, terlebih dahulu dilakukan uji validitas dan reliabilitas. Hasil uji menunjukkan bahwa semua instrumen penelitian telah memenuhi kriteria valid dan reliabel. Penelitian ini menggunakan analisis deskriptif untuk mengetahui persepsi responden terhadap variabel penelitian. Selanjutnya untuk menguji hipotesis, penelitian ini menggunakan Structural Equation Modeling (SEM) dengan pendekatan variance based dengan Partial Least Square (PLS).

\section{PENELITIAN DAN PEMBAHASAN}

\section{Variabel Kepemimpinan}

Variabel kepemimpinan diukur dengan menggunakan 5 indikator. Hasil analisis deskriptif mengenai kepemimpinan dalam penelitian ini ditunjukkan dalam Tabel 2.

Tabel 2

\section{Deskripsi Variabel Kepemimpinan (X1)}

\begin{tabular}{|c|c|c|c|c|c|c|}
\hline \multirow{2}{*}{ Indikator } & \multirow{2}{*}{\multicolumn{4}{|c|}{ Skor $(\%)$}} & \multirow{2}{*}{$\begin{array}{c}\text { Rata- } \\
\text { rata }\end{array}$} & \\
\hline & STS & TS & $\mathrm{N}$ & & & \\
\hline
\end{tabular}




\begin{tabular}{|c|c|c|c|c|c|c|c|}
\hline $\begin{array}{l}\text { Pengarahan tugas pada } \\
\text { bawahan }(\mathrm{X} 1.1)\end{array}$ & 0 & 16.1 & 34,7 & 27,9 & 21.1 & 3,53 & Baik \\
\hline Memotivasi bawahan (X1.2) & 3,4 & 9.3 & 19,4 & 54,2 & 30,5 & 3,63 & Baik \\
\hline Sikap pimpinan (X1.3) & 11.0 & 13,6 & 22,8 & 30,5 & 22,0 & 3,38 & Sedang \\
\hline Pengambilan keputusan (X1.4) & 0 & 14,4 & 22.0 & 26,2 & 37,3 & 3,86 & Baik \\
\hline $\begin{array}{l}\text { Monitoring dan evaluasi } \\
(\mathrm{X} 1.5) \\
\text { Kepemimpinan }\left(\mathrm{X}_{1}\right)\end{array}$ & 0 & 11,0 & 35,6 & 25,4 & 27,9 & $\begin{array}{l}3,69 \\
3,62 \\
\end{array}$ & $\begin{array}{l}\text { Baik } \\
\text { Baik }\end{array}$ \\
\hline
\end{tabular}
Sumber : Data diolah 2017

Berdasarkan Tabel. 2, dapat dijelaskan bahwa variabel kepemimpinan (X1) berada pada katagori baik yang dimana skor rata - rata yang ditunjukkan pada variabel ini adalah 3,62. Jika dilihat berdasarkan masing-masing skor nilai rata-rata indikator, maka indikator yang memiliki skor nilai rata-rata tertinggi yaitu X1.4 (pengambilan keputusan dalam hal ini pimpinanyang menerima pendapat atau masukan yang disampaikan bawahan serta menghargai setiap prestasi yang dicapai bawahan dalam pekerjaannya) dengan nilai rata-rata yaitu 3,86, selanjutnya adalah indikator X1.5 (monitoring dan evaluasi dalam hal ini ketegasan seorang pimpinan dalam melakukan pengawasan memberikan sanksi yang tegas setiap pelanggaran yang dilakukan bawahan) dengan nilai 3,69, sedangkan indikator dengan nilai ratarata terendah adalah X1.3 (sikap pimpinan dalam hal ini perilaku pimpinan yang memberikan bimbingan dengan baik kepada bawahan dalam pekerjaannya membantu memberikan jalan keluar yang baik ketika bawahan mengalami kesulitan dalam bekerja) dengan nilai 3,38, X1.2 (memotivasi bawahan dalam hal ini pimpinan yang memacu semangat kerja bawahan untuk menyelesaikan segala pekerjaan yang menjadi tanggung jawabnyadengan antusias para bawahan dalam menyelesaikan pekerjaan yang dibebankan instansi) dengan nilai rata-rata 3,63dan X1.1 (penyampaian prosedur kerja dalam hal ini pimpinan menyampaikan prosedur kepada bawahan secara tegas sehingga memiliki rasa tanggung jawab serta para 
bawahan dengan kesadaraanya dapat melaksanakan tugas dengan baik) dengan nilai rata-rata 3,53 .

\section{Variabel Pemberdayaan}

Variabel pemberdayaan diukur dengan menggunakan 4 indikator. Hasil analisis deskriptif mengenai pemberdayaan dalam penelitian ini ditunjukkan pada Tabel.3

Tabel 3

Deskripsi Variabel Pemberdayaan (X2)

\begin{tabular}{|c|c|c|c|c|c|c|c|}
\hline \multirow{2}{*}{ Indikator } & \multicolumn{5}{|c|}{ Skor $(\%)$} & \multirow{2}{*}{$\begin{array}{c}\text { Rata- } \\
\text { rata }\end{array}$} & \multirow{2}{*}{ Keterangan } \\
\hline & STS & $\mathrm{TS}$ & $\mathrm{N}$ & $\mathrm{S}$ & SS & & \\
\hline Otoritas (X2.1) & 0 & 11.0 & 19,4 & 31,3 & 38,1 & 3,96 & Baik \\
\hline Akses informasi (X2.2) & 0 & 16,9 & 28,8 & 30,5 & 23,7 & 3,60 & Baik \\
\hline Dukungan Organisasi (X2.3) & 0 & 17,7 & 22.0 & 36,4 & 23,7 & 3,65 & Baik \\
\hline $\begin{array}{l}\text { Penyediaan sumber daya dan } \\
\text { informasi (X2.4) } \\
\text { Pemberdayaan }\left(\mathbf{X}_{\mathbf{2}}\right)\end{array}$ & 0 & 17,8 & 25,4 & 31,3 & 25,4 & $\begin{array}{l}3,64 \\
\mathbf{3 , 7 1}\end{array}$ & $\begin{array}{l}\text { Baik } \\
\text { Baik }\end{array}$ \\
\hline
\end{tabular}

Sumber : Data diolah. 2017

Berdasarkan Tabel3, di atas, dapat dijelaskan bahwa variabel pemberdayaan (X2)berada pada katagori baik yang dimana skor rata - rata yang ditunjukkan pada variabel ini adalah 3,71. Jika dilihat berdasarkan masing-masing skor nilai rata-rata indikator, maka indikator yang memiliki skor nilai rata-rata tertinggi yaitu X2.1 (otoritas dalam hal ini keleluasaan kepercayaan pada bawahanuntuk mengembangkan upaya-upaya inovatif dalam melaksanakan tugas-tugas instansi) dengan nilai rata-rata yaitu 3,96,selanjutnya adalah indikator X2.3 (dukungan dalam hal ini menghargai ide-ide inovatif memberi kesempatan kepada bawahan untuk meningkatkan keterampilan melalui pelatihan internal) dengan nilai 3,65, sedangkan indikator dengan nilai rata-rata terendah adalah X2.4 (pelatihan dalam hal ini ketersediaan akses informasi, dukungan sumber daya (teknologi dan peralatan kerja) yang cukup untuk mengembangkan ide-ide inovatif bawahan yang 
berkaitan dengan pekerjaan) dengan nilai rata-rata 3,64 dan X2.2 (akses informasi dalam hal ini kemudahan memperoleh informasi berkaitan dengan pekerjaan dengan diskusi dalam menerima informasi sesuai dengan bidang pekerjaan) dengan nilai rata-rata 3,60.

\section{Variabel Motivasi}

Variabel motivasi dalam penelitian ini diukur dengan menggunakan 6 indikator. Hasil analisis deskriptif mengenai motivasi dalam penelitian ini ditunjukkan dalam Tabel 4. Berdasarkan Tabel.4, dapat dijelaskan bahwa variabel motivasi (Y1) berada pada katagori baik yang dimana skor rata - rata yang ditunjukkan pada variabel ini adalah 3,55. Jika dilihat berdasarkan masing-masing skor nilai rata-rata indikator, maka indikator yang memiliki skor nilai rata-rata tertinggi yaitu Y1.6 (Pemberian gaji bagi pegawai sudah sesuai dengan beban kerja) dengan nilai rata - rata yaitu 3,93, selanjutnya adalah indikator Y1.3 (Saya selalu terdorong untuk dapat mempengaruhi orang lain dalam lingkungan tempat kerja) dengan nilai 3,72 dan yang terakhir adalah indikator Y1.2 (Saya dapat menunjukkan prestasi pada setiap pekerjaan saya) dan Y1.5 (Saya senang adanya sistem promosi jabatan untuk pengakuan kinerja yang tercapai) dengan nilai rata-rata 3,52, sedangkan indikator dengan nilai rata-rata terendah adalah Y1.1 (Saya bekerja dengan sungguh - sungguh untuk memperbaiki kinerja masa lalu) dan Y1.4 (Saya menyampaikan secara langsung kepada rekan tentang pekerjaan yang tidak sesuai dengan standar kerja) dengan nilai rata - rata 3,40 dan 3,23

Tabel 4

Deskripsi Variabel Motivasi (Y1)

\begin{tabular}{cccccccccc}
\hline & \multicolumn{2}{c}{ Indikator } & & \multicolumn{4}{c}{ Skor (\%) } & Rata & \multirow{2}{*}{ Keterangan } \\
\cline { 3 - 7 } & & & 1 & 2 & 3 & 4 & 5 & -rata & Cukup
\end{tabular}




\begin{tabular}{|c|c|c|c|c|c|c|c|}
\hline \multicolumn{8}{|l|}{$\begin{array}{l}\text { sungguh untuk memperbaiki } \\
\text { kinerja masa lalu (Y1.1) }\end{array}$} \\
\hline $\begin{array}{l}\text { Saya dapat menunjukkan prestasi } \\
\text { pada setiap pekerjaan saya (Y1.2) }\end{array}$ & 0 & 15.3 & 37.3 & 27.1 & 20.3 & 3,52 & Tinggi \\
\hline $\begin{array}{l}\text { Saya selalu terdorong untuk dapat } \\
\text { mempengaruhi orang lain dalam } \\
\text { lingkungan tempat kerja (Y1.3) }\end{array}$ & 0 & 20.3 & 22.0 & 22.0 & 35.6 & 3,72 & Tinggi \\
\hline Saya menyampaikan secara & & & & & & & \\
\hline $\begin{array}{l}\text { langsung kepada rekan tentang } \\
\text { pekerjaan yang tidak sesuai } \\
\text { dengan standar kerja (Y1.4) }\end{array}$ & 0 & 27.1 & 40.7 & 13.6 & 18.6 & 3,23 & Sedang \\
\hline $\begin{array}{l}\text { Saya senang adanya sistem promosi } \\
\text { jabatan untuk pengakuan kinerja } \\
\text { yang tercapai (Y1.5) }\end{array}$ & 0 & 30.5 & 18.6 & 18.6 & 32.2 & 3,52 & Tinggi \\
\hline $\begin{array}{l}\text { Pemberian gaji bagi pegawai sudah } \\
\text { sesuai dengan beban kerja (Y1.6) } \\
\text { Motivasi (Y1) }\end{array}$ & 1.6 & 8.5 & 22.0 & 28.8 & 39.0 & $\begin{array}{l}3,93 \\
3,55\end{array}$ & $\begin{array}{l}\text { Tinggi } \\
\text { Tinggi }\end{array}$ \\
\hline
\end{tabular}

Sumber : Data diolah, 2017

\section{Variabel Kinerja}

Variabel kinerja dalam penelitian ini diukur dengan menggunakan 5 (lima) indikator. Hasil analisis deskriptif variabel kinerja ditunjukkan dalam Tabel 5.

Tabel 5.

Deskripsi Variabel Kinerja (Y2)

\begin{tabular}{lccccccc}
\hline \multirow{2}{*}{ Indikator } & \multicolumn{4}{c}{ Skor (\%) } & $\begin{array}{c}\text { Rata- } \\
\text { rata }\end{array}$ & \multirow{2}{*}{ Keterangan } \\
\cline { 2 - 6 } & STS & TS & N & S & SS & Baik \\
\hline Penyelesaian pekerjaan (Y2.1) & 0 & 20,3 & 30,5 & 22.8 & 26,2 & 3,55 & Baik \\
Inisiatif (Y2.2) & 2,54 & 18,6 & 33,9 & 25,4 & 19,4 & 3,97 & Baik \\
Tanggung Jawab (Y2.3) & 0 & 13,6 & 37,3 & 27,9 & 21,1 & 2,57 & Tidak Baik \\
Kerja sama (Y2.4) & 1,6 & 12,7 & 33,0 & 39,0 & 14,4 & 3,64 & Baik \\
Kedisiplinan (Y2.5) & 7,6 & 13,5 & 18,6 & 35,6 & 24,5 & 3,55 & Baik \\
Kinerja (Y2) & & & & & & $\mathbf{3 , 4 5}$ & Baik \\
\hline
\end{tabular}

Sumber : Data diolah 2017.

Berdasarkan Tabel 5, dapat dijelaskan bahwa variabel kinerja (Y2) berada pada katagori baik yang dimana skor rata - rata yang ditunjukkan pada variabel ini adalah 3,45. Jika dilihat berdasarkan masing-masing skor nilai rata-rata indikator, maka indikator yang memiliki skor nilai rata-rata tertinggi yaitu Y2.2 (Inisiatif dalam hal ini pegawai bisa mengambil jalan keluar, mengambil alternatif dengan baik dalam menyelesaikan pekerjaan) dengan nilai rata-rata yaitu 3,97, selanjutnya adalah indikator Y2.4 (kerja sama dalam hal ini pegawai mampu menjalin kerja 
sama selalu mengikuti prosedur kerja yang telah ditentukan institusi dalam menyelesaikan pekerjaan) dengan nilai 3,64 dan yang terakhir adalah indikator Y2.1 (Penyelesaian pekerjaan dalam hal ini peyelesaian tugas yang diberikan pimpinan sesuai target yang ditentukandengan bantuan peralatan kerja yang disediakan lembaga) dan Y2.5 (kedisiplinan dalam hal ini pegawai yang tidak pernah meninggalkan tugas saat jam kerja waktu pelayananselalu datang tepat waktu sesuai jam kerja yang ditetapkan) dengan nilai rata-rata 3,55, sedangkan indikator dengan nilai rata-rata terendah adalah Y2.3 (tanggung jawab dalam hal ini pegawai memiliki tanggung jawab yang baik selalu bersikap positif terhadap semua pekerjaan yang diberikan) dengan nilai 2,57.

\section{ANALISIS PARTIAL LEAST SQUARE (PLS)}

Penelitian ini menggunakan pendekatan model persamaan struktural (Struktural Equation Modeling/SEM) berbasis variance atau lebih dikenal dengan SEM-PLS. Hal ini dilakukan mengingat SEM-PLS merupakan sebuah metode analisis yang powerfull yang mampu menyelesaikan model tanpa harus mengikuti kaidah-kaidah regresi pada umumnya yaitu data harus berdistribudi normal, multikolonearitas, dan autikorelasi. Metode analisis PLS memiliki dua tahapan evaluasi yaitu 1) evaluasi model pengukuran (outer model), dan 2) evaluasi model struktural (inner model).

\section{Evaluasi Model Pengukuran (Outer Model)}

Evaluasi model pengukuran (outer model) bertujuan untuk mengetahui validitas dan reliabilitas indikator - indikator yang mengukur variabel laten yaitu; variabel kepemimpinana (X1), variabel pemberdayaan (X2), variabel motivasi (Y1), 
dan variabel kinerja (Y2). Evaluasi model pengukuran dilakukan dengan memeriksa convergent dan discriminant validity dari indikator konstruk serta composite reliability untuk blok indikator.

\section{Composite reliability}

Composite reliability bertujuan untuk menguji nilai reliabilitas antara blok indikator dari konstruk yang membentuknya.

Tabel. 6

\section{Hasil Uji Composite Reliability}

\begin{tabular}{lc}
\hline \multicolumn{1}{c}{ Variabel } & Composite Reliability \\
\hline Kepemimpinan & 0,886 \\
Pemberdayaan & 0,894 \\
Motivasi & 0,835 \\
Kinerja & 0,917 \\
\hline \multicolumn{2}{c}{ Sumber : Data diolah, 2017 }
\end{tabular}

Hasil Composite reliability dikatakan baik, jika nilainya di atas 0,70. Pengujian composite reliability bertujuan untuk menguji validitas instrumen dalam suatu model penelitian secara khusus untuk indikator refleksif. Hasil pengujian composite reliability disajikan pada Tabel 6. Tabel. 6, memperlihatkan nilai composite reliability ke empat variabel yang membentuk model penelitian semuanya diatas 0,70 . Hal ini berarti bahwa semua indikator refleksif yang membentuk model penelitian adalah reliabel.

\section{Convergent Validity}

Perhitungan convergent validity bertujuan untuk mengetahui item-item yang membentuk indikator variabel laten. Hasil uji convergen validity diukur berdasarkan besarnya nilai loading faktor disajikan pada Tabel 7, berikut.

\section{Tabel 7}

Validitas Konvergen

\begin{tabular}{ccccc}
\hline Variabel & Indikator & $\begin{array}{c}\text { Outer } \\
\text { loading }\end{array}$ & T - statistik & Keterangan \\
\hline Kepemimpinan & $\mathrm{X} 1.1$ & 0.858 & 19.491 & Valid \\
X1 & $\mathrm{X} 1.3$ & 0.814 & 16.297 & Valid \\
\hline
\end{tabular}




\begin{tabular}{ccccc}
\hline \multirow{2}{*}{ Pemberdayaan } & X1.5 & 0.877 & 24.969 & Valid \\
X2 & X2.2 & 0.818 & 15.446 & Valid \\
& X2.3 & 0.871 & 23.239 & Valid \\
& X2.4 & 0.885 & 26.249 & Valid \\
Motivasi & Y1.1 & 0.708 & 6.884 & Valid \\
Y1 & Y1.2 & 0.554 & 4.966 & Valid \\
& Y1.3 & 0.675 & 11.061 & Valid \\
& Y1.4 & 0.682 & 6.413 & Valid \\
& Y1.5 & 0.745 & 12.461 & Valid \\
Kinerja & Y1.6 & 0.689 & 10.452 & Valid \\
Y2 & Y2.1 & 0.858 & 20.060 & Valid \\
& Y2.2 & 0.773 & 14.201 & Valid \\
& Y2.3 & 0.832 & 19.853 & Valid \\
& Y2.4 & 0.810 & 13.999 & Valid \\
\hline
\end{tabular}

Sumber : Data diolah, 2017

Hasil pengujian pada Tabel 7, di atas menunjukkan bahwa seluruh nilai outer loading indikator konstruk memiliki nilai di atas 0,5 . Jadi dapat disimpulkan bahwa pengukuran ini memenuhi persyaratan validitas konvergen.

\section{Discriminant Validity}

Selain menguji convergent validity, di dalam analisis $P L S$ juga menguji validitas diskriman (discriminant validity). Metode pengujiannya adalah membandingkan nilai square root of average variance extracted $(\sqrt{ } A V E)$ setiap konstruk dengan korelasi antar konstruk lainnya dalam model. Jika nilai pengukuran awal kedua metode tersebut lebih baik dibandingkan dengan nilai konstruk lainnya dalam model, maka dapat disimpulkan bahwa konstruk tersebut memiliki nilai discriminant validity yang baik atau sebaliknya. Hasil pengujian discriminant validity disajikan dalam Tabel 8.

\section{Tabel 8}

\section{Hasil Pengujian Discriminant Validity}

\begin{tabular}{lcc}
\hline \multicolumn{1}{c}{ Variabel } & Koefisien AVE & Keterangan \\
\hline Kepemimpinan & 0,722 & Valid \\
Pemberdayaan & 0,737 & Valid \\
Motivasi & 0,760 & Valid \\
Kinerja & 0,688 & Valid \\
\hline
\end{tabular}


Sumber: Data diolah, 2017

Hasil pengujian pada Tabel 8 menunjukkan bahwa semua akar $A V E$ pada variabel penelitian memiliki nilai di atas 0,5. Jadi dapat disimpulkan bahwa pengukuran ini memenuhi persyaratan validitas diskriminan

\section{Q-Square Predictive Relevance $\left(Q^{2}\right)$}

$Q$-Square Predictive Relefance $(Q 2)$ bertujuan untuk mengetahui seberapa besar variabel terikat dapat diprediksi dengan tepat oleh variabel bebas. nilai $\mathrm{Q}^{2}$ mulai dari 0 sampai dengan 1 , dimana semakin dekat dengan nilai 1 , artinya nilai prediksi semakin baik, sedangkan sebaliknya semakin dekat dengan nilai 0 , artinya nilai prediksi semakin lemah. Nilai $\mathrm{R}^{2}$ ditunjukkan dalam Tabel 9.

Tabel 9.

Nilai R2 Variabel endogen

\begin{tabular}{ll}
\hline & R-square \\
Motivasi & 0.649 \\
Kinerja & 0.838 \\
\hline Sumber: Data diolah, 2017 &
\end{tabular}

Nilai $Q^{2}$ predictive-relevance diperoleh dengan rumus:

$$
\begin{aligned}
& \mathrm{Q}^{2}=1-\left(1-\mathrm{R}_{1}{ }^{2}\right)\left(1-\mathrm{R}_{2}{ }^{2}\right)=\mathrm{Q}^{2}=1-(1-0,663)(1-0,838) \\
& =\mathrm{Q}^{2}=1-(0,337)(0,162)==\mathrm{Q} 2=1-0,054=\mathbf{Q}^{2}=\mathbf{0 , 9 4 6}
\end{aligned}
$$

Berdasarkan hasil perhitungan $\mathrm{Q}^{2}$ di atas, nilai $\mathrm{Q}^{2}$ adalah sebesar 0,946 atau 94,6\% (kuat). Hasil ini memberikan makna bahwa variabel-variabel bebas (kemimpinan(X1)pemberdayaan(X2), motivasi (Y1), dan Kinerja (Y2)) memberikan prediksi yang kuat terhadap variabel terikatnya (kinerja).

\section{Hasil Pengujian Hipotesis Penelitian}

Penelitian ini menggunakan pendekatananalisis Partial Least Square(PLS) untuk melakukan uji dan analisis terhadap hipotesis penelitian yang telah 
dikemukakan sebelumnya.Hasil analisis data dengan menggunakan PLS menunjukkan bahwa loading factor masing - masing indikator variabel di dalam model memiliki nilai diatas 0,5 kecuali indikator X1.2 yaitu kurang kejesalan dari pimpinan dalam memberikan arahan, sehingga para bawahan kurang melaksanakan tugas dengan baik memiliki nilai $(0,219)$, X1.4 yaitu rendahnya motivasi dari pimpinan sehingga karyawan kurang antusias dalam menyelesaikan pekerjaan yang dibebankan instansi memiliki nilai $(0,219)$, dan X2.1 yaitu informasi yang menjadi masukan oleh bawahan belum sesuai dengan bidang pekerjaan karyawan memiliki nilai $(0,210)$ yang memiliki nilai loading faktor kurang dari 0,50 , sehingga indikator tersebut dikeluarkan dari model penelitian. Selanjutnya, setelah analisis kembali tanpa indikator X1.2, X1.4, X21, maka seluruh indikatortelah memenuhi kriteria pengujian.

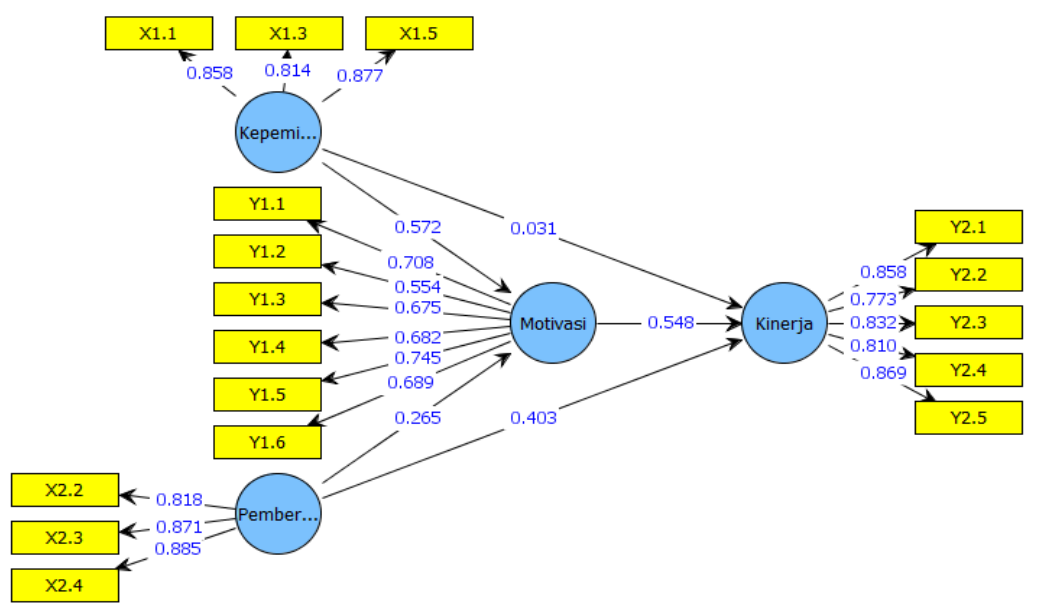

Gambar 2. Hasil Output Partial Least Square (PLS)

Tabel. 9

Hasil Uji Hipotesis

\begin{tabular}{lcccc}
\hline Hubungan Antar Variabel & $\begin{array}{c}\text { Original sample } \\
\text { estimate }\end{array}$ & $\begin{array}{c}\text { Mean of } \\
\text { subsamples }\end{array}$ & T-Statistic & Keterangan \\
\hline Kepemimpinan -> Motivasi & 0.572 & 0.584 & 3,146 & Signifikan
\end{tabular}




\begin{tabular}{ccccc} 
Pemberdayaan -> Motivasi & 0.265 & 0.584 & 1,979 & Signifikan \\
Kepemimpinan -> Kinerja & 0.031 & 0.051 & 0,194 & Tidak Signifikan \\
Pemberdayaan -> Kinerja & 0.403 & 0.403 & 3,582 & Signifikan \\
Motivasi -> Kinerja & 0.548 & 0.530 & 5,582 & Signifikan \\
\hline
\end{tabular}

Sumber : Data diolah, 2017

Hasil pengujian hipotesis pengaruh langsung kepemimpinan terhadap motivasi dengan nilai sebesar 0,572 dan t-statistics3,146. Nilai t-statistics 3,146 lebih besar dari 1,896 (alpha 5\%), maka pengaruh kepemimpinan terhadap motivasi adalah signifikan. Dengan demikian, maka hipotesis 1 (H1) yang menyatakan bahwa kepemimpinan berpengaruh positif signifikan terhadap motivasi diterima.

Hasil pengujian hipotesis pengaruh langsung pemberdayaan terhadap motivasi dengan nilai sebesar 0,265 dan t-statistics1,979. Nilai t-statistics 1,979 lebih besar dari 1,896 (alpha 5\%), maka pengaruh pemberdayaan terhadap motivasi adalah signifikan. Dengan demikian, maka hipotesis 2 (H1) yang menyatakan bahwapemberdayaan berpengaruh positif signifikan terhadap motivasi diterima.

Pengujian hipotesis pengaruh langsung komitmen organisasional terhadap kualitas layanan menunjukkan nilai sebesar 0,031dengan t-statistik 0,051, Karena t-statistics sebesar 0,051 lebih kecil dari 1,96 (alpha 5\%), maka hipotesis 3 (H3) yang menyatakan bahwa kepemimpinan berpengaruh positif signifikan terhadap kinerja tidak dapat diterima atau ditolak.

Hasil pengujian hipotesis pengaruh langsung kepemimpinan terhadap motivasi dengan nilai sebesar 0,403 dan t-statistics3,582. Nilai t-statistics 3,582 lebih besar dari 1,896 (alpha 5\%), maka pengaruh pemberdayaan terhadap kinerja 
adalah signifikan. Dengan demikian, maka hipotesis 4 (H4) yang menyatakan bahwa pemberdayaan berpengaruh positif signifikan terhadap kinerja diterima.

Hasil pengujian hipotesis pengaruh langsung kepemimpinan terhadap motivasi dengan nilai sebesar 0,548 dan t-statistics5,582. Nilai t-statistics 5,582 lebih besar dari 1,896 (alpha 5\%), maka pengaruh kepemimpinan terhadap motivasi adalah signifikan. Dengan demikian, maka hipotesis 5 (H5) yang menyatakan bahwa motivasi berpengaruh positif signifikan terhadap kinerja diterima.

\section{Pengaruh Kepemimpinan terhadap Motivasi}

Hasil analisis menunjukkan bahwa kepemimpinan berpengaruh positif signifikan terhadap motivasi. Hasil ini mengindikasikan bahwa kepemimpinan pegawai pada Dinas Pendidikan Pemuda dan Olah Raga Kabupaten Tabanan yang dipersepsikan oleh karyawan yang diukur berdasarkan indikator: Pengarahan tugas pada bawahan, memotivasi bawahan, sikap pimpinan, pengambilan keputusan dan monitoring dan evaluasi yang dilakukan bawahan mampu meningkatkan motivasi kerja.

Hal ini dapat diartikan bahwa jika seorang pemimpin mampu untuk mengarahkan dengan tegas para bawahan dalam melaksanakan tugas dengan pengarahan yang tepat kepada bawahan, penyampaian prosedur kerja yang baik, sikap pemimpin yang patut di teladani didalam melaksanankan tugas, kebijakan pengambilan keputusan dengan melibatkan pegawai dan ketegasan pimpinan dalam pemberian sanksi atas pelanggaran yang dilakukan bawahan yang nantinya akan dapat memotivasi para pegawai untuk bekerja lebih baik lagi. Hasil penelitian ini sejalan dengan hasil - hasil penelitian sebelumnya yang dilakukan oleh Chipunza et 
al. (2011), Chaudhry and Javed (2012) dan Barbuto dan Gifford (2012) yang menunjukan bahwa terdapat hubungan antara kepemimpinan dengan motivasi.

\section{Pengaruh Pemberdayaan terhadap Motivasi}

Hasil analisis menunjukkan bahwa pemberdayaan berpengaruh positif terhadap motivasi. Hal ini menunjukkan bahwa faktor pemberdayaan yang di ukur oleh indikator: otoritas, akses informasi, dukungan organisasi dan penyediaan sumber daya dan informasi mampu meningkatkan motivasi pegawai. Penelitian Conger and Kanungu (1988) menyatakan bahwa jika Organisasi memberikan keleluasaan kepada pegawai untuk mengembangkan kreatifitas dalam menyelesaikan pekerjaan, organisasi memberikan kepercayaan kepada pegawai untuk mengembangkan upaya-upaya inovatif dalam melaksanakan tugas-tugas instansi, pegawai diberikan kemudahan memperoleh informasi berkaitan dengan pekerjaan dengan diskusi yang baik, pegawai menerima informasi sesuai dengan bidang pekerjaan, instansi sangat menghargai kreatifitas pegawai dalam pekerjaan, instansi memberi kesempatan kepada pegawai untuk meningkatkan keterampilan melalui pelatihan internal, instansi menyediakan akses informasi yang pegawai perlukan untuk menyelesaikan pekerjaan yang dibebankan dan instansi menyediakan dukungan sumber daya (teknologi dan peralatan kerja) yang cukup untuk mengembangkan kreatifitaspegawai yang berkaitan dengan pekerjaan, dengan demikian akan membuat pegawai tersebut cenderung memiliki motivasi yang lebih tinggi sehingga mereka merasa nyaman dan termotivasi dalam melaksanakan pekerjaanyang diberikan oleh instansi. Hasil penelitian ini sejalan dengan hasil hasil penelitian sebelumnya yang dilakukan oleh Swarnalatha dan Prasanna (2012), 
Tutar et al.(2011), Drake et al. (2007) dan Gagne et al. (1997), yang mana penelitinnya menyatakan adanya hubungan antara pemberdayaan dengan motivasi.

\section{Pengaruh Kepemimpinan terhadap Kinerja}

Hasil analisis mengenai pengaruh kepemimpinan terhadap kinerja menunjukkan hasil yang positif tetapi tidak signifikan. Hal ini mengindikasikan bahwa kepemimpinan pegawai Dinas Pendidikan Pemuda dan Olah Raga Kabupaten Tabanan yang diukur berdasarkan indikator: Pengarahan tugas pada bawahan, memotivasi bawahan, sikap pimpinan, pengambilan keputusan danmonitoring dan evaluasi tidak mampu mendorong peningkatan kinerja pegawai pada pegawai Dinas Pendidikan Pemuda dan Olah Raga Kabupaten Tabanan.

Hal ini berkorelasi dengan peran kepemimpinan, dimana sikap pimpinan yang memacu dengan baik semangat kerja bawahan untuk menyelesaikan segala pekerjaan yang menjadi tanggung jawabnya, pimpinan memotivasi dengan antusias para bawahan dalam menyelesaikan pekerjaan yang dibebankan instansi, pimpinan memberikan bimbingan dengan baik kepada bawahan yang mengalami hambatan dalam pekerjaannya, sikap pimpinan selalu membantu memberikan jalan keluar yang baik ketika bawahan mengalami kesulitan dalam bekerja, pimpinan selalu menerima pendapat atau masukan yang disampaikan bawahan dalam mengambil keputusan, sikap pimpinan yang menghargai setiap prestasi yang dicapai bawahan dalam pekerjaannya, peran pimpinan yang selalu melakukan pengawasan dengan ketat pada setiap bawahan dan sikap pimpinan memberikan sanksi yang tegas setiap pelanggaran yang dilakukan oleh pegawai. Sehingga mampu meningkatkan kinerja yang lebih baik. 


\section{Pengaruh Pemberdayaan terhadap Kinerja}

Hasil analisis menunjukkan bahwa pemberdayaan berpengaruh positif terhadap kinerja. Faktor pemberdayaan yang dipersepsikan responden melalui indikator: otoritas, akses informasi, dukungan organisasi dan penyediaan sumber daya dan informasi mampu meningkatkan kinerja terhadap pegawai pada Dinas Pendidikan Pemuda dan Olah Raga Kabupaten Tabanan.

Berdasarkan penelitian Andrea (2007) dapat diartikan bahwa keberadaan pemberdayaan yang diberikan pada pegawai oleh instansi melalui keleluasaan kepada pegawai untuk mengembangkan kreatifitas dalam melaksanakan tugas-tugas instansi. Instansi mendukung pegawai dengan kepercayaan untuk mengembangkan upaya-upaya inovatif dalam melaksanakan tugas-tugas instansi. Instansi memberikan kemudahan akses dalam memperoleh informasi berkaitan dengan pekerjaan dengan diskusi yang baik, pegawaiselalu diberikan informasi sesuai dengan bidang pekerjaan, instansi selalu menghargai kreatifitas pegawaisehingga mampu menyelesaikan pekerjaannya, instansi memberi pelatihan internaluntuk pegawai dalam meningkatkan keterampilan, ketersediaan akses informasi yang sangat diperlukan pegawai dalam menyelesaikan pekerjaan dan instansi menyediakan dukungan sumber daya dalam hal dukungan peralatan kerja dan teknologi dalam mengembangkan kreatifitaspegawaidalam meningkatkan kinerjanya. Hasil penelitian ini tidak sejalan dengan hasil penelitian sebelumnya terkait dengan kepemimpinan dan kinerja yang dilakukan oleh beberapa peneliti seperti Dionneet al. (2004), Beverly et al. (2008), Chi et al. (2008), Pradeep dan Prabhu (2011) dan Sahin (2011) yang menyimpulkan bahwa kepemimpinan berpengaruh positif dan signifikan terhadap kinerja. 


\section{Pengaruh Motivasi terhadap Kinerja}

Hasil analisis menunjukkan bahwa motivasi berpengaruh positif terhadap kinerja. Hal ini menunjukkan bahwa faktor motivasi mampu meningkatkan kinerja pegawai pada Dinas Pendidikan Pemuda dan Olah Raga Kabupaten Tabanan.

Hal ini dapat di artikan bahwa motivasi dapat dilihat dari sikappegawai bekerja dengan sungguh-sungguh untuk memperbaiki kinerja masa lalu, pegawaidiharapkan dapat menunjukkan prestasi pada setiap pekerjaannya, pegawaiharus terdoronguntuk dapat mempengaruhi orang lain dalam lingkungan tempat kerjanya, pegawai harus menyampaikan secara langsung kepada rekan tentang pekerjaan yang tidak sesuai dengan standar kerja instansi, pegawaidisediakan sistem promosi jabatan untuk pengakuan kinerja yang tercapai dan pemberian gaji bagi pegawai yang sesuai dengan beban kerja dari instansi yang secara langsung akan mampu membantu di dalam meningkatkan kinerja pegawai pada Dinas Pendidikan Pemuda dan Olah Raga Kabupaten Tabanan.

Hasil penelitian ini sesuai dengan temuan-temuan penelitian sebelumnya yang dilakukan oleh Wang (2009) dan Salleh et al. (2011), Mawoli and Babandako (2011), Siwantara (2010), Yuniari dan Teni Waisnawini (2009) membuktikan hal yang sama, dimana peran motivasi berdampak positif terhadap kinerja pegawai sehingga memberikan hasil positif terhadap kinerja instansi.

\section{IMPLIKASI PENELITIAN}

Implikasi penting penelitian ini adalah dibuktikannya beberapa hasil penelitian sebelumnya terkait dengan kepemimpinan, pemberdayaan, motivasi dan kinerja. Hasil analisis menunjukkan bahwa persepsi pegawai atas kepemimpinan, 
pemberdayaan, motivasi dan kinerja semuanya dipersepsikan sangat baik oleh para pegawai Dinas Pendidikan Pemuda dan Olah Raga Kabupaten Tabanan.Penelitian ini juga memberikan implikasi penting terkait dengan teori tentang kepemimpinan dan pemberdayaan yang dikaitkan dengan motivasi dan kinerja. Hasil penelitian ini mendukung penelitian-penelitian sebelumnya, terutama yang berkaitan dengan kepemimpinan, pemberdayaan, motivasi dan kinerja. Namun disisi lain, penelitian ini belum mampu membuktikan bahwa kepemimpinan berperan langsung dengan peningkatan kinerja pegawai.

Implikasi praktis yang bisa diungkapkan dari hasil penelitian ini adalah dapat dibuktikannya peran mediasi motivasi pada pengaruh kepemimpinan dengan kinerja. Hal ini mengindikasikan bahwa pegawai yang merasa puas dengan perhatian dan motivasi yang diberikan oleh pimpinannya telah terbukti mampu meningkatkan motivasi pegawai untuk bekerja yang berimplikasi kepada semakin baiknya kinerja yang ditampilkan oleh pegawai Dinas Pendidikan Pemuda dan Olah Raga Kabupaten Tabanan.

Penelitian ini memiliki keterbatasan pada objek penelitian di kantor dinas Pendidikan Pemuda dan Olah Raga Disamping itu, keterbatasan lain penelitian ini adalah digunakannya pegawai untuk mempersepsikan kepemimpinan dan pemberdayaan yang mereka berikan untuk melihat bagaimana nantinya dapat berpengaruh terhadap motvasi dan kinerja dalam bekerja. Oleh sebab itu, perlu dilakukan pengembangan di dalam menentukan dimensi - dimensi yang digunakan untuk mengukuran kepemimpinan dan pemberdayaan yang digunakan sehingga sehingga mendapatkan hasil penelitian yang lebih baik dan valid. 


\section{SIMPULAN DAN SARAN}

Berdasarkan permasalahan penelitian, tujuan, hipotesis, dan hasil pembahasan pada bab sebelumnya, maka dapat disimpulkan sebagai berikut. Kepemimpinan berpengaruh positif signifikan terhadap motivasi. Hal ini mengandung makna bahwa kepemimpinan yang baik, akan dapat meningkatkan motivasi kerja pegawai. Pemberdayaan berpengaruh signifikan secara langsung terhadap motivasi. Hal ini mengandung makna, bahwa pemberdayaan yang baik dapat berdampak pada peningkatan motivasi kerja pegawai.Kepemimpinan tidak berpengaruh positif signifikan terhadap kinerja. Hal ini mengandung makna, bahwa kepemimpinan tidak mampu meningkatkan kinerja secara nyata. Pemberdayaan berpengaruh signifikan secara langsung terhadap kinerja. Hal ini mengandung makna, bahwa dengan semakin baiknya pemberdayaan dilaksanakan, akan dapat berdampak positif pada peningkatan kinerja pegawai.Motivasi berpengaruh signifikan secara langsung terhadap kinerja. Hal ini mengandung makna, bahwa motivasi yang baik dapat berdampak pada peningkatan kinerja pegawai.

Berdasarkan hasil penelitian dan kesimpulan, berikut ini beberapa saran sebagai berikut. Mempertahankan dan meningkatkan kepemimpinan dengan lebih memberikan motivasi kepada para pegawai dalam menyelesaikan pekerjaan yang dibebankan instansi. Instansi harus dapat lebih memberi kesempatan bagi pegawai untuk mengembangkan ide - ide inovatif dalam menyelesaikan pekerjaan yang telah dipersepsikan baik oleh pegawai agar pegawai tersebut mempunyai rasa keyakinan bahwa mereka merupakan bagian dari instansi.Meningkatkan motivasi terhadap pegawai dengan melakukan pemberian sistem promosi jabatan untuk pengakuan kinerja yang tercapai.Mempertahankan kinerja dengan selalu memberikan perhatian 
terhadap pegawai dan memberikan motivasi serta memberikan kepercayaan bahwa mereka bisa menyelesaikan tugas yang diberikan dengan baik.

\section{REFERENSI}

Abdul Qayyum Chaudhry, Husnain Javed. 2012. Impact of Transactional and Laissez Faire Leadership Style on Motivation. International Journal of Business and Social Science. Vol. 3 No. 7. pp. 258-264.

Andrea R. Drake, Jeffrey Wong, Stephen B. Salter. 2007. Emporwerment, Motivation, and Performance : Examining the Impact of Feedback and Incentives On Nonmanagement Employees. Behavioral Researchin In Accounting. Vol. 7, pp. 71-89.

Ari Fadzilah. 2006. Analisis Pengaruh Pemberdayaan Karyawan dan Self Of Efficacy Terhdap Kinerja Karyawan Bagian Penjualan (Studi Kasus Pada PT. Sinar Sosro). Jurnal Studi Manajemen dan Organisasi. Vol.3, No.1, Halaman 12-27.

Azman Ismail, Hasan Al-Banna Mohamed, Ahmad Zaidi Sulaiman, Mohd Hamran Mohamad and Munirah Hanim Yusuf. 2011. An Empirical Study of the Relationship between Transformational Leadership, Empowerment and Organizational Commitment. Business and Economics Research Journal, 2(1): 89-107

Bernadine, Susilo Supardo. 2002. Kepemimpinan dan dasar-dasar pengembangannya. Yogyakarta: Andi

Bernardin, H. John, dan Joyce E.A Russel. 2003. Human resource management (An Experimental Approach International Edition). Mc. Graw-Hill Inc. Singapore.

Beverly Alimo-Metcalfe, John Alban-Metcalfe, Margaret Bradley, Jeevi Mariathasan, Chiara Samele. 2008. The impact of engaging leadership on performance, attitudes to work and wellbeing at work. Journal of Health Organization and Management. 22(6): pp. 586-598

Brenda L. Maka, Hy Sockel, 2001. A confirmatory factor analysis of is employee motivation and retention. Journal Information \& Management 38: pp. 265276

Catherine Cheung, Tom Baum, Alan Wong, 2012. Relocating empowerment as a management concept for Asia. Journal of Business Research 6(5): pp.36-41

Chan Yuen Fook, Linton Brinten, Gurnam Kaur Sidhu, Foo Say Fooi, 2011. Relationships between Psychological Empowerment with Work Motivation and Withdrawal Intention among Secondary School Principals in Malaysia. JournalProcedia Social and Behavioral Sciences 15(1): pp. 2907-2911 
Ching-Wen Wang, Kai-Tang Fan, Chang-Tseh Hsieh, Michael L Menefee. 2009. Impact Of Language On Team Creative Performance. The Journal of Computer Information Systems. Stillwater. Vol. 50, Edisi 1; pg. 133-402.

Chun-Fang Chiang, Tsung-Sheng Hsieh, 2012. The impacts of perceived organizational support and psychological empowerment on job performance: The mediating effects of organizational citizenship behavior. International Journal of Hospitality Management 3(1): h: 180-190

Christine Lundberg, Anna Gudmundson, Tommy D. Andersson, 2009. Herzberg's Two-Factor Theory of work motivation tested empirically on seasonal workers in hospitality and tourism. Journal Tourism Management 30: h: 890-899

Conger, J. dan Kanungo, R. 1988. "The Empowerment Process: Integrating Theory and Practice." Academy of Management Review, Vol. 13, No. 3: 471-482.

Desak Sintiasih, Ketut, Ni Nyoman Kerti Yasa, Ni Wayan Mujiati dan Ayu Desi Indrawati, 2013. Peran Pemberdayaan dalam Menopang Kreativitas Sumber Daya Manusia sebagai sumber daya saing Industri Kecil dan Menengah (IKM) di Kabupaten Badung Provinsi Bali. Jurnal Kependudukan dan Sumber Daya Manusia, 9(2): pp. 105-112

Durga Devi Pradeep , N.R.V. Prabhu. 2011. The Relationship between Effective Leadership and Employee Performance. International Conference on Advancements in Information Technology. 20(1): H:1-56

Eugen Avram, Iustin Priescu, 2012. Access to information and empowerment perspectives in health services. Journal Procedia - Social and Behavioral Sciences. 33, pp.949-953

Faruk Sahin. 2011.The interaction of self-leadership and psychological climate on job performance.African Journal of Business Management. Vol. 5 . pg. 1787-1794.

Fauzilah Salleh, Zaharah Dzulkifli, Wan Amalina Wan Abdullah,Nur Haizal Mat Yaakob. 2011.The Effect of Motivation on Job Performance of State Government Employees in Malaysia. International Journal of Humanities and Social Science. Vol. 1 No. 4. pp. 147-154.

Fairchild, Henry Pratt. 1996. Dictionary of Sociology. New Jersey: Littlefield, Adams \& Co

Flavia Cavazotte, Valter Moreno, Mateus Hickmann, 2012. Effects of leader intelligence, personality and emotional intelligence on transformational leadership and managerial performance. Journal The Leadership Quarterly 2(3): pp. 443-455

Gabriel J. Byrne, Frank Bradley, 2007. Culture's influence on leadership efficiency: How personal and national cultures affect leadership style. Journal of Business Research. 60: pp. 168-175

Ghozali, Imam. 2012. Aplikasi Analsiis Multivariate Dengan Program SPSS. Edisi Kedua. Semarang: Penerbit Universitas Diponegoro. Pustaka Utama. 
Gorda, I Gusti Ngurah. 2006. Manajemen Sumber Daya Manusia. Cetakan Ketiga. Denpasar : Astabrata Bali.

Handoko T. Hani. 2006. Manajemen Personalia dan Sumber Daya Manusia Edisi 2, Yogyakarta : BPFE UGM

Hariandja, Mariot Tuafendi. 2002. Manajemen Sumber Daya Manusia. Jakarta : Grasindo.

Hasan Tutar, Mehmet Altinoz, Demet Cakiroglu. 2011. The effects of employee empowerment on achievement motivation and the contextual performance of employees. African Journal of Business Management. Vol. 5, No. 15, pp. 63186329.

Heri Susanto dan Nuraini Aisiyah, 2010. Pengaruh kepemimpinan dan budaya kerja terhadap kinerja karyawan di Kantor Pertanahan Kabupaten Kebumen melalui motivasi sebagai variabel intervening. Jurnal Magista. 74(22): h: $15-38$

Hsin Kuang Chi, Huery Ren Yeh, Cherng-Ying Chiou. 2008. The Mediating Effects of Internal Marketing on Transformational Leadership and Job Performance of Insurance Salespersons in Taiwan. The Business Review, Cambridge. Vol. 11, No 1, pp. 173-180.

Irene Hau-siu Chow, Thamis Wing-chun Lo, Zhenquan Sha, Jiehua Hong, 2006. The impact of developmental experience, empowerment, and organizational support on catering service staff performance. Journal of Hospitality Management 25, pp.478-495

John E. Barbuto, Jr, Gregory T. Gifford. 2012. Motivation and Leader-Member Exchange : Evidence Counter to Similarity Attraction Theory.International Journal of Leadership Studies. Vol. 7, No 1, pp. 18-28.

Khan, Sharafat. 1997. They Key to being a Leader Company: Empowerment, Journal Personality and Partisipation, pp. 44-45

Kanter, A. 1997. Human Resource Management. Terjemahan. Jakarta: Bratama Media

Luthans, Fred. 2011. Organizational Behavior: An Evidence -Based approach.New York: The McGrow-Hill Companies, Inc.

Mai Ngoc Khuong and Dang Thuy Hoang. 2015. The Effects of Leadership Styles on Employee Motivation in Auditing Companies in Ho Chi Minh City, Vietnam. International Journal of Trade, Economics and Finance. 6(4): h: 210-217

Mangkunegara, A. A. Anwar Prabu. 2011. Manajemen Sumber Daya Manusia Organisasi. Bandung: PT. Remaja Rosdakarya

Manullang, 2007. Manajemen Sumber Daya Manusia, Penerbit BPFE, Yogyakarta

Mary Ann Hocutt and Thomas H. Stone, 1998. The Impact of Employee Empowerment on the Quality of a Service Recovery Effort. Journal of Quality Management, 3(1): pp. 117-132 
Marylene Gagne, Caroline B. Senecal, Richard Koestner. 1997. Proximal Job Characteristics, Feelings of Empowerment, and Intrinsic Motivation: A Multidimensional Model. Journal of Applied Social Psychology. Vol. 27, No. 14, pp. 1222-1240.

Mc. Donald and C.A. Morgan. 2002. Animal Nutrition. $5^{\text {th }}$ Edition. Longman Scientific and Technical, Inc. New York

Miftah, Thoha. 2003. Perilaku Organisasi Konsep Dasar dan Perilakunya. Cetakan VII.

Mohammed Abubakar Mawoli, Abdullahi Yusuf Babandako. 2011. An Evaluation Of Staff Motivation, Dissatisfaction and Job Performance In An Academic Setting. Australian Journal of Business and Management Research. Vol.1 No.9. pp. 1-13.

Nawawi Hadari, H. 2003. Manajemen Sumber Daya Manusia untuk Basic yang Kompetitif, Cetakan Kelima, Yogyakarta : Gajah Mada University Press.

Nitisemito, A.S. 2000. Manajemen Personalia (Manajemen Sumber Daya Manusia). Jakarta:Ghalia Indonesia.

P1nar Gungor, 2011. The Relationship between Reward Management System and Employee Performance with the Mediating Role of Motivation: A Quantitative Study on Global Banks. Journal Procedia Social and Behavioral Sciences 2(4): pp.1510-1520

Riduwan dan Sunarto. 2007. Pengantar Statistika Untuk Penelitian Pendidikan, Sosial, Ekonomi, dan Bisnis. Bandung : Alfabeta.

Robbins, S.P., and Judge, T.A. 2008. Perilaku Organisasi, Edisi Kedua belas,Jakarta: Salemba Empat.

Sedarmayanti. 2007. Manajemen Sumber Daya manusia, Reformasi Birokrasi dan Manajemen Pegawai Negeri Sipil. Cetakan Pertama. Bandung : PT Refika Aditama.

Seung-Bum Yang, Sang Ok Choi. 2008. Employee empowerment and team performance. Team Performance Management. Vol. 15, No. 5, pp. 289-301

Soeprihanto, John. 2000 Manajemen Sumber Daya Manusia. Universitas Terbuka. Karunika, Jakarta

Simamora, Henry. 2006. Manajemen Sumber Daya Manusia. Edisi 1. Yogyakarta.

Siwantara. 2010. Pengaruh Kompetensi Profesional dan Motivasi Kerja serta Iklim Organisasi Terhadap Disiplin Kerja dan Kinerja Dosen Politeknik Negeri Bali. Jurnal Manajemen Fakultas Ekonomi Universitas Udayana. 4(1): h:119.

Sugiyono, 2010, Metode Penelitian Bisnis. Bandung: CV. Alfabeta.

Spreitzer, G. M. 1995. Psychological empowerment in workplace: dimensions, measurement, and validation. Academy of Management Journal, 38(5), $1442-1465$. 
Shelley D Dionne, Francis J Yammarino, Leanne E Atwater, William D Spangler. 2004. Transformational leadership and team performance. Journal of Organizational Change Management. Bradford, Vol. 17, No.2, pp. 177.

Stewart, Aileen Mitchell, 2006. Empowering People, Cetakan kedelapan, Kansius, Yogyakarta

Swarnalatha.Prasanna.T. 2012. A study on employee empowerment to motivate the employees in health care industry in a private multi-speciality organization. Asian Journal Of Management Research. Vol. 3. pp. 107-115.

Terri A. Scanduraa and Ethlyn A. Williams, 2004. Mentoring and transformational leadership: The role of supervisory career mentoring. Journal of Vocational Behavior 65: h: 448-468

Wiwiek Harwiki, 2013. Influence of Servant Leadership to Motivation, Organization Culture, Organizational Citizenship Behavior (OCB), and Employee's Performance in Outstanding Cooperatives East Java Province, Indonesia. Journal of Business and Management. 8(5): h: 50-58

Yuniari Made, Teni Waisnawini Luh Gede. 2009. Pengaruh Motivasi dan Lingkungan Kerja serta Motivasi Kerja terhadap Semangat Kerja dan Kinerja Karyawan PT. BTDC Nusa Dua. Jurnal Bisnis dan Kewirausahaan, Vol.5, No.2, pp. 144-152. 